\title{
高血圧自然発症ラット，脳卒中易発症ラットの血漿 レニン活性，とくに降圧羭投与の影響について
}

\author{
中田瑛浩 \\ PLASMA RENIN ACTIVITY IN STROKE-PRONE AND -RESISTANT \\ SPONTANEOUSLY HYPERTENSIVE RATS: RELATIONSHIP TO \\ SOME ANTIHYPERTENSIVE DRUGS
}

Teruhiro Nakada

Hypertension-Endocrine Branch, National Heart, Lung and Blood Institute, National Institutes of

Health, Bethesda, Maryland 20014 U.S.A.

Pepstatin $(200 \mu \mathrm{g} / \mathrm{kg})$, clonidine $(200 \mu \mathrm{g} / \mathrm{kg})$, phenoxybenzamine (POB) $(1 \mathrm{mg} / \mathrm{kg}$ or $3.5 \mathrm{mg} / \mathrm{kg})$ or propranolol ( $3 \mathrm{mg} / \mathrm{kg}$ ) was subcutaneously injected twice daily to male young Wistar Kyoto rats (WKY), spontaneously hypertensive rats (SHR) and stroke-prone spontaneously hypertensive rats (SHRSP) for consecutaive 14 days. It was found 1) that pepstatin failed to reduce the blood pressure in SHR and SHRSP, and PRA in these genetically hypertensive strains were similar to that of the saline-treated control animals. However, a slight decrease of blood pressure $(6.2 \%, \mathrm{p}<0.05)$ concomitant with an increase of PRA $(81.5 \%), p<0.05)$ was observed in the pepstatin-treated WKY. 2) that there was a significantly lower blood pressure in clonidine-treated WKY $(16.2 \%, \mathrm{p}<0.001)$, SHR $(22.6 \%, \mathrm{p}<0.001)$ and SHRSP $(37.7 \%, \mathrm{p}<0.001)$ as compared to that of saline-treated räts; that PRA of WKY, but not that of SHR, or SHRSP, was decreased by treatment of clonidine $(79.3 \%, \mathrm{p}<0.01)$. 3) that lower dose of POB significantly $(\mathrm{p}<0.001)$ decreased blood pressure in WKY $(11.5 \%)$, SHR $(12.8 \%)$ and SHRSP $(25.1 \%)$; that higher dosage of it caused significant $(\mathrm{p}<0.001)$ reduction of blood pressure and an increase of heart rate in each strain concomitant with remarkable increase $(\mathrm{p}<0.001)$ of PRA in WKY $(328.5 \%)$, SHR $(336.2 \%)$ and SHRSP $(249.7 \%)$. 4) that blood pressure and heart rate of propranolol-treated WKY was similar to those of control rats, however PRA was lower than that of the control rats. Propranolol administration to SHR or SHRSP did not lower PRA, but caused bradycardia with a paradoxical rise in blood pressure in SHR at the age of 7 weeks $(7.0 \%, \mathrm{p}<0.001)$ or 8 weeks $(7.3 \%, \mathrm{p}<0.01)$ as well as 8-week-old SHRSP $(5.8 \%, \mathrm{p}<0.001)$.

These results indicate three important variables. First, renin-angiotensin system in young genetically hypertensive rats did not play an important role in the pathogenesis of genetic hypertension. Second, adrenergic receptor of WKY appeared to be more sensitive than that of SHR or SHRSP except the response of heart rates of SHR or SHRSP treated with propranolol. Third, pepstatin showed no hypotensive effect on SHR or SHRSP.

要旨：異つた作用機序をもつ降圧剂，新しく開発された protease inhibitor を若年性の高血圧自然発症ラット (SHR)，脳卒中易発症ラット (SHRSP) に投与し，以下のごとき成績を得た。

1） pepstatin をSHR, SHRSP 飞投与しても, 血圧は下降せず，血漿レニン活性（PRA）も不変であつた. 正常血圧ラット（WKY）への本剂投与は血圧下降と PRA の上昇をきたした。

2) clonidine は SHR, SHRSP の PRA を変えないが，血圧下降作用は著しい. 本剂は WKY の血压と PRA を著減させた。

現：富山医科薬科大学医学部泌尿器科 
3） phenoxybenzamine 投与は WKY, SHR, SHRSP の血圧下降，心拍数增加，PRA の上昇をきたせた。

4） propranolol はSHR, SHRSP の血圧上昇を惹起させたが PRA は不変で西つた。心拍数は減少した。

一方 WKY の血厈, 心拍数は不変であつたが PRA は減少した。

以上の成績より，以下のごとき結論党得た。1）若年性 SHR，SHRSP のレニン・アンギオテンシン系は genetic hypertension の原因とは無関係である.2) WKY の adrenergic receptor はSHR, SHRSP のそれよ り，propranolol の実験で得た成績の一部をのぞきょり sensitive である．3）in vivo での皮下投与実験で は, pepstatin $200 \mu \mathrm{g} / \mathrm{kg}$ の SHR, SHRSP 八の投与注, 降圧作用, レニン抑制作用を示さない。

\section{緒 言}

高血压自然発症ラット（SHR） はヒトの本態性高血压 症のモデル動物と見做されている。とのレニン・アンギ オテンシン系の直進が，昇圧の病因となり得るか㔻かに ついては一致した見解がない，因に SHR の血漿レニン 活性（PRA）は上昇しているとする報告もあり ${ }^{1)}$ ，逆の 見解も㐫る ${ }^{2)}$. 最近，岡本らは急激な血正上景上，それ に伴う脳卒中を容易に惹起させる脳卒中易発症高係圧自 然発症ラット (SHRSP) の作成に成功したが3 ${ }^{3}$, この 動物のレニン・アンギオテンシン系, および降圧剤の 影響を検査した論文は少い，著者はこれら genetically hypertensive rats, とくに SHRSP の高血圧の発症にレニ ンが関与しているか否かを知る目的で, 異つたタイプの 降圧剂ないしレニン抑制剂を若年性高血圧ラットに投与 し，若干の知見を得たので，ここに述べる.

\section{実験動物および方法}

SHR は岡本・青木が Wistar Kyoto rat (WKY) よ り，その選択的兄妹交配により分離したもので)，その 第13代が NIH に移された. SHRSP はSHRの $F_{32,34} よ$ り最近, 岡本らが作成したもので゙), 最も脳血管性病変 が強いといわれている $A_{3}$ substrain が NIH の Animal Production Section にて飼育されている。これらのラッ トをVeterinary Resources Branch より 4 週路にて実験 室㳊し, NIH open formula A $(0.36 \% \mathrm{Na}, 0.85 \% \mathrm{~K}$ 含育 $)^{5)}$ にて飼育し，2週間環境に適合させた後，94匹の WKY, 72匹の SHR, 75匹の SHRSP に以下のごとき薬 物を投与した。すなわち，第 I 群のラットには生理食塩

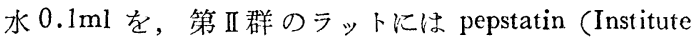
of Microbial Chemistry, Tokyo, Japan) $200 \mu \mathrm{g} / \mathrm{kg}$ を, 第群のラットには clonidine $\mathrm{HCl}$ (Boehringer Ingelheim) $200 \mu \mathrm{g} / \mathrm{kg}$ を，第IV群のラットには phenoxybenzamine $\mathrm{HCl}$ (POB) (Smith, Kleine and French Co., Philadelphia) $1 \mathrm{mg} / \mathrm{kg}$ を, 第V群のラットには POB $3.5 \mathrm{mg} / \mathrm{kg}$ を, 第VI群のラットには propranolol $\mathrm{HCl}$ (propranolol) (Ayerst Laboratoies, New York) $3 \mathrm{mg} / \mathrm{kg}$ を,

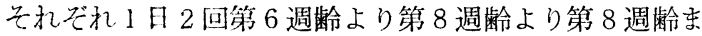
で連日皮下注射した。な和第 I 第VI群のラットは11〜 25匹の WKY 8 ～19匹の SHR, 7 〜6匹の SHRSP 上 り成り, pepstatinは $\mathrm{pH} 7.5$ の phosphate buffered saline に溶解させ, clonidine, propranolol は生理食塩水に溶 解させて動物に投与した。収縮期血圧は無麻酔にて tail cuff method にて测定 し ${ }^{6}$ ，その脈波を Physiograph

(Desk ModelType DMP-4A, E \& M Instrument Co., Inc. Houston，Texas）に記録した. 血圧と心拍数は実験 期間中， 5 回測定した。 14 日間の上記薬物投与の後，す ベてのラットをギロチン法にて 屠殺し，駆幹血 $3 \mathrm{ml}$ を $7.5 \mathrm{mg}$ の EDTA $\mathrm{Na}_{2}$ を含有する冷却試騟管内に採取 した．血液は $4{ }^{\circ} \mathrm{C}, 1,200 \mathrm{~g}$ で20分間遠沈し，血漿を凍 結保存した。 PRA 測定は Katz \& Smith ${ }^{7}$ が開発した angiotensin の radioimmunoassay で, Yun ら ${ }^{8)}$ の文献に 詳細に述べられている. PRA は $\mathrm{ng} / \mathrm{ml} / \mathrm{hr}$ で示した。

\section{実験成䋶}

薬剂無投与 の 6 週齢の WKY の血圧は $123 \pm 2 \mathrm{mmHg}$ (平均士標準誤差)で, 軽度に上下しながら加㱓ととも に僅かに上昇し， 8 週龄では 6 週齢より $7 \mathrm{mmHg}$ 高值を 示与。薬剤無投与の SHRSP の血圧上昇は著しく, 同週

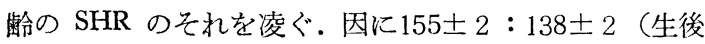
42日目), $168 \pm 4: 149 \pm 5$ (生後45日目), 179土4： $157 \pm 2$ (生後49日目), $184 \pm 2 ： 158 \pm 2$ (生後52日目), $191 \pm 2 ： 164 \pm 2$ (生後56日目) （各, SHRSP : SHR, $\mathrm{mmHg}$, 平均士標準誤差) であつた (Fig. 1). Fig. 1, 2 亿示すごとく，8 週齢の薬剤無投与の WKY, SHR, SHRSP の心拍数は $428 \pm 12,475 \pm 10,495 \pm 12$ (各, beats/min, 平均士標準誤差) で, WKY に比し SHR, SHRSP の心拍数は有意に高い（それぞれ $\mathrm{p}<0.01, \mathrm{p}<$ $0.001)$. pepstatin 投与は SHR, SHSP の血圧上昇を阻 止できない.わずかに 8 週龄の SHRSP の心拍数を 11.5 \%減少させたにすぎない. clonidine 投与はどのラット の血圧も低下させる。その低下率は 7 ないし 8 週龄の WKY で10.2ないし16.2\%同週㛔の SHR で17.2\%ない 
Fig. 1 Variation of systolic blood pressure $(\mathrm{mmHg})$ and heart rate (beats $/ \mathrm{min}$ ) of young male rats. Each group consisted of 11-25 WKY, 8-19 SHR or 7-16 SHRSP was give drug treatment twice daily from 6 to 8 weeks of age such as saline, pepstatin, clonidine, two dosages of POB or propranolol. Dosis and method of these drug administration as in MATERIALS AND METHODS. Numbers in blanks indicate number of animals. Each bar represents the S.E.M.

$* * * \mathrm{p}<0.001, * * \mathrm{p}<0.01, *_{\mathrm{p}}<0.05$; compared to age-matched saline-treated rats in each strain.

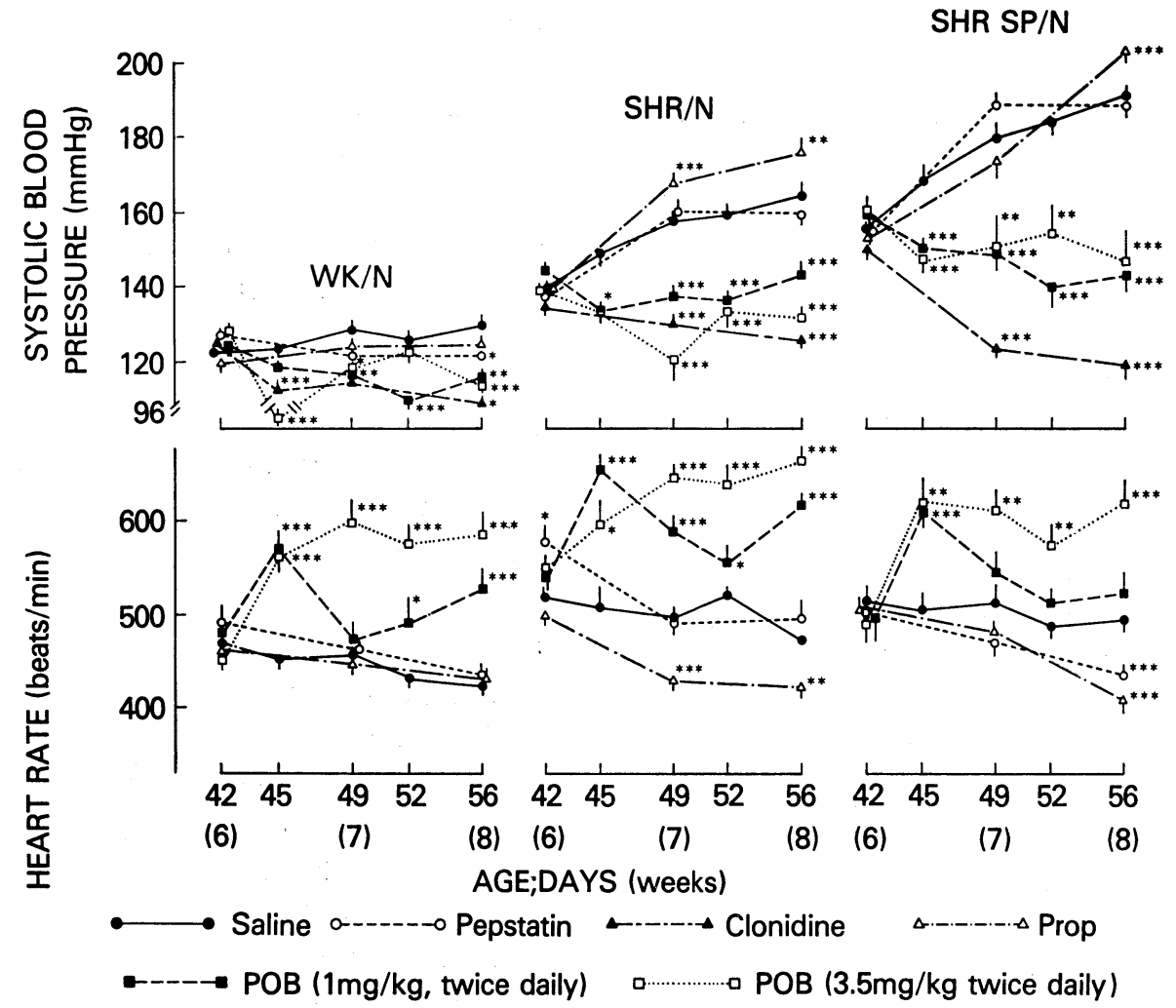

し22.6\%, 同週齢の SHRSP で26.2ないし37.7\%であつ た. $\mathrm{POB}$ の $1 \mathrm{mg} / \mathrm{kg}$ ない $3.5 \mathrm{mg} / \mathrm{kg}$ の投与は，どのラ ット内血圧も漸減ないし急減させた. 因に POB $1 \mathrm{mg} / \mathrm{kg}$ の WKY に対する投与で，その 血王下降度は $4.1 \%$ (N.S.)（生後45日目)，9.4\%（p<0.01）（生後49日目）, $12.7 \%(\mathrm{p}<0.001)$ (生後52日目)，11.5\%（p<0.001） (生後56日目) であり，同剂 $3.5 \mathrm{mg} / \mathrm{kg}$ 投与 で $22.0 \%$ $(\mathrm{p}<0.001)$ (生後45日目)，7.8\%（p<0.05）（生後49 日目), $2.4 \%$ (N.S.) (生後52日目), $12.3 \%(\mathrm{p}<0.001)$ (生後56日目) であつた。 SHR に対する POB 投与は dose dependent な血圧下降を生じたが SHSP に対して はたそらではなかつた（Fig. 1)。生後45日目のSHRを 除き, POB 投与は dose dependent な心拍数増動を惹起 させた (Fig. 1). propranolol の投与を受けた WKY の血圧，心拍数は 無変化であつた (Fig. 1) 一方, 同剤投与を受けた SHR, SHRSP に徐脈と血圧上昇が認められた（Fig. 2). 因に propranolol 投与を受けた 7 ないし 8 週齢の SHR の血压 は7.6\% $(\mathrm{p}<0.001)$ ないし $7.3 \%(\mathrm{p}<0.01)$ 上昇し， 心拍数は $13.3 \%(\mathrm{p}<0.001)$ ないし $10.1 \%(\mathrm{p}<0.01)$ 減少した. propranolol 投与を受けた 8 週齢の SHPSP は血圧で $5.8 \%(\mathrm{p}<0.001)$ 上昇し，心拍数で $17.2 \%$ $(\mathrm{p}<0.001)$ 減少した。

8 週齢のラットの PRA は Fig. 2 に示すごとくで, 薬剂無投与の WKY, SHR, SHRSP の PRA はそれぞ れ $7.33 \pm 0.61,5.47 \pm 0.64,8.49 \pm 0.97 \mathrm{ng} / \mathrm{ml} / \mathrm{hr}$ (平均 土標準誤差) であつた。 pepstatin 投与を受けた WKY の PRA は13.30土2.39ng/ml/hr (平均土標準誤差) で, 
Fig. 2 Systolic blood pressure ( $\mathrm{mmHg}$ ), heart rate (beats/min) and PRA ( $\mathrm{ng} / \mathrm{ml} / \mathrm{hr}$ ) of 8-week-old WKY, -SHR and -SHRSP treated from 6 to 8 weeks of age with the same medications as in Fig. 1. Dosis, method of the drug administrations or shematic representation as in Fig. 1. Vertical bars: 土standard error of means. $* * * \mathrm{p}<0.001, * * \mathrm{p}<0.01, * \mathrm{p}<0.05 ;$ compared to WKY in the same medication group. Wp $<0.001,+\mathrm{p}<0.01,+\mathrm{p}<0.05$; compared to paired comparisons.
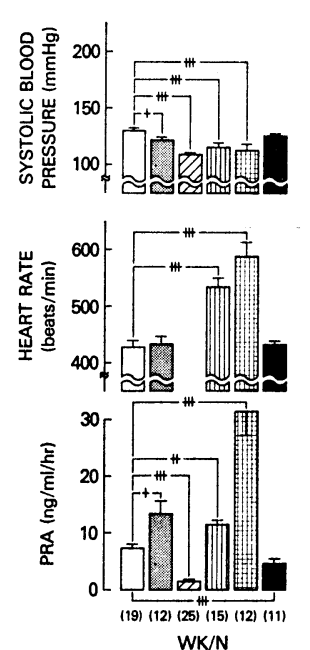

WK/N

$\square$ Saline

IIII) POB (1mg/kg twice daily)

POB $(3.5 \mathrm{mg} / \mathrm{kg}$ twice daily)

Propranolol
Pepststin
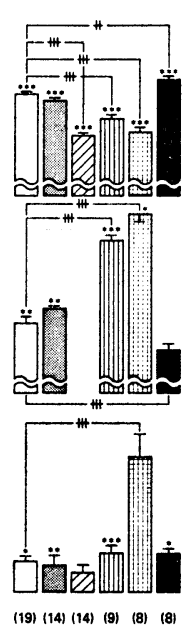

SHR/N
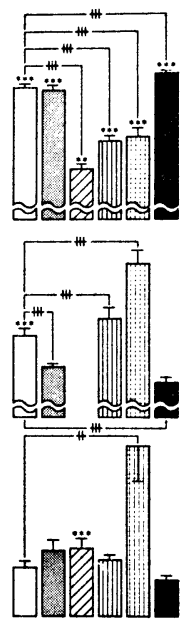

(16) (14) (16) (14) (8) (7) SHR SP/N

対照 WKY より僅かに $(\mathrm{p}<0.05)$ 高いが, 血圧は軽度 に $(\mathrm{p}<0.05)$ 低い $(122 \pm 3$ vs $130 \pm 2 \mathrm{mmHg}$, 各平均士 標準篔差).一方, pepstatin 投与を受けた SHR, SHRSP

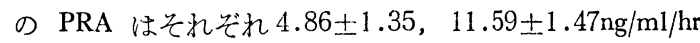
(平均土標準誤差) で, 対照ラットの PRA と有意差は なかつた。 clonidine 投与を受けた WKY の PRA は $1.52 \pm 0.41 \mathrm{ng} / \mathrm{ml} / \mathrm{hr}$ (平均士標準誤差) 之対照 WKY の それより低い $(\mathrm{p}<0.001)$ が，本剂投与の SHR, SHRSP

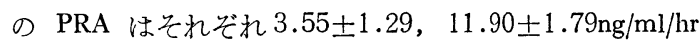
(平均士標準誤差) で, 対照ラットの PRA と同レベル であつた. POBを $1 \mathrm{mg} / \mathrm{kg}$ ないし $3.5 \mathrm{mg} / \mathrm{kg}$ をラットに 投与すると，WKY の PRA は11.21士0.89ないし31.41 $\pm 4.35 \mathrm{ng} / \mathrm{ml} / \mathrm{hr}$ (平均土標準誤差), SHR のそれは6.77 土1.31ないし $23.86 \pm 3.83 \mathrm{ng} / \mathrm{ml} / \mathrm{hr}$ (平均士標準誤差),

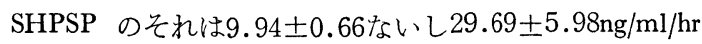

(平均土標準誤差) と dose related に上昇した. propranolol 投与を受けた WKY の血圧, 心拍数は対照 WKY とほぼ等しいが，PRA は4.52士0.61 ng $/ \mathrm{ml} / \mathrm{hr}$ と低值 であつた $(\mathrm{p}<0.001)$ ，一方，同剤投与を受けた SHR， SHRSP の PRA は対照ラットの PRA と有意差はなか つた.

\section{考按}

pepstatin は acid protease の specific inhibitor とし て知られているが9)， in vitroに拈いてレニン基質の抑 制作用を有することが判明した ${ }^{1011)}$ 。 in vivo において も予め $0.005 \mathrm{dog}$ unit のレニンを投与して 血圧上昇を 来たしてから， $50 ， 200 \mu \mathrm{g}$ の pepstatin を静注すると 降圧效果が得られたとの報告もある ${ }^{11)}$. 本実験に於て は, pepstatin SHR, SHRSP の高血圧の発症を阻止し 得なかつた。本薬剤の投与で第一に，レニンは SHR， SHRSP の高血圧の成因と考光難いこと．第二に 1 日 2 回，14日間の pepstatin 皮下注射では SHR, SHRSP の PRA が有意の変化を示さないことが判明した. pepstatin は pepsin の inhibitor であり, pepsin は $\mathrm{pH} 7$ 前後 でレニン基質に作用してアンジオテン I を生じることか $ら^{12)}$, 最近, pepstatin のレニン・アンジオテンシン系 への作用が注目されている(10)1112). pepstatin の投与を受 けた SHR, SHRSP の PRA が対照ラットのそれと大差 なかつた理由は pepstatin の in vivo での効果が短時間 に限られていること なとどより, 本実験での本剂の投与. 量, 投与方法が PRA を変化させるのに適切でなかつた のか, これら genetically hypertensive rats のレニン・ アンジオテンシン系は交進して拈らず, 本剂に反応しに くかつたのか, in vivo での本剤の作用は in vitro と異 るのかなどの可能性が考えられる in vivo における本 剂のレニン分泌抑制作用を明確に示した論文はなく, 現 在, 上記成績の真の理由は不明である.

clonidine の正常血圧ラットに対する降圧作用は麻酔 を施行されたウィスターラットト13), 施行されないウィス ターラット ${ }^{14)}$, ピスを受けたウィスターラット ${ }^{15)}$ ，フロ 七ミド投与で体内の $\mathrm{Na}$ が減少した $\mathrm{SD}$ ラット ${ }^{16)}$ にお いて知られている. 本実験においても clonidine 投与で WKY の血圧は下降し， PRA は減少した。しかしなが ら PRA の減少が WKY の降圧の原因とは即断でき ない. clonidine の末梢の $\alpha$-adrenergic blocking 作用 も部分的に血圧下降に貢献するが ${ }^{17)}$, 主として中枢の adrenergic receptor agonist としての作用で血圧は下降 すると考えられている ${ }^{14)}$. clonidine の SHR に対する 
経口投与は降圧作用を示すことが Roba ら ${ }^{18)}$, Sugimoto ら ${ }^{19)}$ により示された。本実験では clonidine の皮下投与

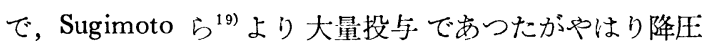
作用を呈した。 SHR の sympathetic nerve activity は 穴進して扣り，降圧療法によるその低下が報告されて いる ${ }^{20)}$. 一方, sympathetic nervous system は少くとも レニン分泌に 部分的に関与していることが知られてい る ${ }^{21)}$ 。従つて, clonidine 投与を受けた SHR, SHRSP が，PRA はほとんど変化させずに血圧のみ下降したこ と (Fig. 1) は，レニン過分泌がこれら高血圧動物の昇 圧因子と見なし得ないことを示している。しかし，その 解釈は複雑となる。 clonidine のレニン分泌抑制作用が, 腎の perfusion pressure の低下によりレニン分泌が促進 されるため隠されことが可能性の一つとして著者には考 えられる、しかしながら上記の現象の完全な解明は不明 である。

POB を正常血圧ラットまたは高血圧ラットに投与す ると, 最初は cardiac depression が生じ, ついで連続投 与による $\alpha$-adrenolytic action で血圧が下降すると見な されている222. 中枢のみならず, 末梢に打ける $\alpha$-receptor の抑制は， $\beta$-receptor を刺激しレニン過分泌が生じ たと推測される。

正常食塩含有食にて飼育したSHR, SHRSP に対して propranolol を投与すると, 徐脈とともに軽度の血圧上 昇が生じた (Fig. 2). propranolol 投与に上る血圧の paradoxical な上昇は, Forman \& Mulrow によりすで に報告されている ${ }^{23)}$. 一方, propranolol のSHR に及洼 す顕著な降圧作用も少なからず報告されている ${ }^{1822425)}$. このよらな不一致は, 実験動物の年㱓差にのみ帰するこ とはできない.ちなみに, Forman \& Mulrow ${ }^{23)}$ は生後 $6 \sim 8$ カ月の SHR を用いて抒り, 本実験では $6 \sim 8$ 週 秢のSHRを用いてほぼ同様の成績を得た。著者は実験 成績の不一致は投与量の差に帰因すると考えたい。SHR の降圧をきたしたとする報告を調べるに，propranolol の投与量は，著者の投与量の 10 倍 ${ }^{18)}, 12$ 倍 ${ }^{25}$ または 17 倍 ${ }^{24)}$ にも達している. 大量の propranolol が局所的に anesthetic properties を示して血圧を下降させたとも考 えられる. propranolol 投与を受けた WKY の PRA は 対照 WKY に比し低いが, 前者の血圧は後者のとれとほ ぼ等しいこと. propranolol 投与を受けた SHR, SHRSP と薬剤無投与のそれらの PRA レベルに有意差はなく, 前者群の血厌が paradoxical 飞上昇したことより, 若年 性 WKY, SHR, SHRSP のレニンの変動が, それらの血
圧上昇に直接, 結びつくとは考鼻離い。

\section{結 語}

pepstatin $200 \mu \mathrm{g} / \mathrm{kg}$, clonidine $200 \mu \mathrm{g} / \mathrm{kg}$, РОВ $1 \mathrm{mg} / \mathrm{kg}$ ないし $3.5 \mathrm{mg} / \mathrm{kg}$ ，または propranolol $3 \mathrm{mg} / \mathrm{kg}$ を 1 日 2 回，14日間，若年性の WKY，SHR，SHRSP に皮下投与 し，以下のごとき成績を得た。

1) pepstatin は SHR, SHSP の高血圧の発症を阻止し 得ず，それらラットの PRA は対照ラットのそれと同レ ベルであつた. pepstatin 投与を受けた WKY の血圧は 軽度に下降し $(6.2 \%, \mathrm{p}<0.05)$, PRA b軽度に $(\mathrm{p}<$ 0.05) 上昇した。

2) clonidine 投与は WKY, SHR, SHRSP の血圧を それぞ机16.2\% ( $\mathrm{p}<0.001), 22.6 \%(\mathrm{p}<0.001), 37.7$ $\%(\mathrm{p}<0.001)$ 減少させた. 本薬剤投与の SHR, SHRSP の PRA は対照ラットのそれと汪ぼ等しいが, 本剤投与 の WKY の PRA は薬剤無投与 WKY の79.3\%低下し た $(\mathrm{p}<0.01)$.

3) $\mathrm{POB} 1 \mathrm{mg} / \mathrm{kg}$ 投与は有意の $(\mathrm{p}<0.001)$ 血圧下 降を WKY (11.5\%), SHR (12.8\%), SHRSP (25.1 \%) 飞惹起させ，心拍数の増加をWKY (35.8\%), SHR (40.4\%), SHRSP (25.1\%) 飞惹起させた.ささらに本 剂 $3.5 \mathrm{mg} / \mathrm{kg}$ の投与を受けた WKY, SHR, SHRSP の PRA は，それぞれ薬剂無投与ラットのそれより WKY で328.5\% ( $<<0.001)$, SHR で336.2\% ( $<<0.001)$, SHRSP で249.7\% ( $\mathrm{p}<0.001)$ 高值であつた.

4） propranolol 投与を受けた WKY の血圧，心拍数 に著変はなかつたが，その PRA は薬剤無投与の WKY の PRA に比し $38.3 \%(\mathrm{p}<0.001)$ 低值であつた. propranolol を SHR, SHRSP 飞投与しても, それらの PRA は低下せず，徐脈と paradoxical な血圧上昇が SHR で は 7 週桧 $(7.0 \%, \mathrm{p}<0.001)$ 打よび 8 週齿 $(7.3 \%, \mathrm{p}<$ 0.01) 飞認められ，SHRSP では 8 週秢 $(5.8 \%, \mathrm{p}<$ 0.001) に認められた.

以上の成績より，以下のごとき結論を得た１）若 年性 SHR, SHRSP のレニン・アンジオテンシン系は genetic hypertension 0原因と無関係である。2) WKY の adrenergic receptor は, SHR, SHRSP のそれより propranolol 投与で見た心拍数の成績を除き，より sensitive response を示す．3） in vivo での皮下投与の慢 性実験では, pepstatin $200 \mu \mathrm{g} / \mathrm{kg}$ の SHR, SHRSP への 投与は降任作用，血漿レニン低下作用を示さない。

稿を終るにあたり，pepstatinを提供していただき，そ れと関する御助言を睗わった梅沢浜夫博士，青柳高明博 
士（微生物化学研究所）に深謝する。本実験の施行に 直接，御協力，御援助をいただいた Walter Lovenberg 博士, John C.H. Yun 博士, Frederic C. Bartter 博士 (Hypertension-Endocrine Branch. National Heart, Lung and Blood Institute, NIH, Bethesda, Maryland 20014, U.S.A.) に深謝する。

（本論文の要旨は, 第23回日本腎臟学会総会に沶いて 報告した。）

\section{文献}

1) Sen, S., Smeby, R.R. and Bumpus, F.M.: Renin in rats with spontaneous hypertension. Circ. Res., 31, 876-880, 1972.

2) Shiono, K. and Sokabe, H.: Renin-angiotensin system in hypertensive rats. Am. J. Physiol., 231, 1295-1299, 1976.

3) Okamoto, K., Yamori, Y. and Nagaoka, A.: Establishment of the stroke-prone spontaneously hypertensive rats (SHR). Circ. Res., 34-35 (Suppl. 1), 143-153, 1974.

4) Okamoto, K. and Aoki, K.: Development of spontaneously hypertensive rats. Jap. Circ. J., 27, 282-293, 1963.

5) Knapka, J.J., Smith, K.P. and Judge, F.J.: Effect of open and closed formula rations on the performance of three strains of laboratory mice. Lab. Anim. Sci., 24, 480-487, 1974.

6) Pfeffer, J.M., Pfeffer, M.A. and Frohlich, E.D.: Validity of an indirect tail-cuff method for determining systolic arterial pressure in unanesthetized normotensive and spontaneously hypertensive rats. J. Lab. Clin. Med., 78, 957-962, 1971.

7) Katz, F.H. and Smith, J.A.: Radioimmunoassay of angiotensin I: Comparison of two renin activity methods and use for other measurements of the renin system. Clin. Chem., 18, 528-533, 1972.

8) Yun, J.C.H., Delea, C.S., Bartter, F.C. and Kelly, G.: Increase in renin release after sinoaortic and cervical vagotomy. Am. J. Physiol., 230, 777-783, 1976.

9) Umezawa, H., Aoyagi, T., Morishima, H., Matsuzaki, M., Hamada, M. and Takeuchi, T.: Pepstatin, a new pepsin inhibitor produced by actinomycetes. J. Antibiot. (Tokyo), 23, 259-262, 1970.

10) Orth, H., Hackenthal, E., Lazar, J., Miksche, U. and Gross, F.: Kinetics of the inhibitory effect of pepstatin $c n$ the reaction of renin with rat plasma substrate. Circ. Res., 35, 52-55, 1974.
11) Gross, F., Lazar, J. and Orth, H.: Inhibition of the renin-angiotensinogen reaction by pepstatin. Science, 175, 656, 1972.

12) Franz de Fernández, M.T., Paladini, A.C. and Delius, A.E.: Isolation and identification of a pepstatin. Biochem J., 97, 540—546, 1965.

13) Pettinger, W.A., Keeton, T.K., Campbell, W.B. and Harper, D.: Evidence for a renal $\alpha$-adrenergic receptor inhibiting renin release. Circ. Res., 38, 338-346, 1976.

14) Lapski, J., Przybylski, J. and Solnicka, E.: Reduced hypotensive effect of clonidine after lesions of the nucleus tractus solitarii in rats. Europ. J. Pharmacol., 38, 19—22, 1976.

15) Armstrong, J.M. and Boura, A.L.A.: Effects of clonidine and guanethidine on peripheral sympathetic nerve function in the pithed rat. Brit. J. Pharmacol., 47, 850 -852, 1973.

16) Pals, D.T.: Hypotensive effect of clonidine during sodium deplet in the rat. Circ. Res., 37, 795-801, 1975.

17) Dollery, C.T. and Reid, J.L.: Central norarednergic neurons and the cardiovascular actions of clonidine in the rabbit. Brit. J. Pharmac., 47, 206-216, 1973.

18) Roba, J., Lambelin, G. and Schaepdryver, A.F.: Antihypertensive activity of four blocking agents in spontaneously hypertensive rats. Arch. Int. Pharmacodyn., 200, 182-190, 1972.

19) Sugimoto, S., Hashida, M. and Kasahara, K.: Effect of prolonged administration of clonidine to spontaneously hypertensive rats on blood pressure, cerebral norepinephrine content and angiographic finding in the kidney. Jap. Circ. J., 40, 319-328, 1976.

20) Judy, W.V., Watanabe, A.M., Henry, D.P., Besch, H.R. Jr., Murphy, W.R. and Hockel, G.M.: Sympathetic nerve activity. Role in regulation of blood pressure in the spontaneously hypertensive rat. Circ. Res. (Suppl. 2), 38, 21-29, 1976.

21) Ganong, W.F.: Biogenic amines, sympathetic nerves, and renin secretion. Fed. Proc., 32, 1782-1784, 1973.

22) Jacquey, A.M. et Wepierre, J.: Action de la phénoxybenzamine et de la guanéthidine sur láctivité cardiovasculaire globale et les débits sanguins nutritionnels du rat normal et du rat hypertendu. Annales pharmaceutiques françaises, 33, 413-424, 1975.

23) Forman, B.H. and Mulrow, P.J.: Effect of propranolol on blood pressure and plasma renin activity in the spcntaneously hypertensive rat. Circ. Res., 35, 215-221, 1974. 
24) Weiss, L., Lundren, Y. and Folkow, B.: Effect of prolonged treatment with adrenergic $\beta$ receptor antagonosts on blood pressure, cardiovascular design and reactivity in spontaneously hypertensive rats (SHR). Acta Physiol. Scand., 91, 447-457, 1974.

25) Ljung, B., Åbland, B., Dahlöf, C., Henning,
M. and Hultberg, B.: Impaired vasoconstriction nerve function in spontaneously hypertensive rats after long-term treatment with propranolol and metropropranolol. Blood Vessels, 12, 311-315, 1975.

（1980年 6 月 9 日受付） 